Article

\title{
Food, Eating, and the Gastrointestinal Tract
}

\author{
Dan M Livovsky ${ }^{1}$, Teorora Pribic ${ }^{2,3,4}$ and Fernando Azpiroz ${ }^{2,3,4, *(\mathbb{D})}$ \\ 1 Digestive Diseases Institute, Shaare Zedek Medical Center, Hebrew University of Jerusalem, \\ 9103102 Jerusalem, Israel; danlivo@yahoo.com \\ 2 Digestive System Research Unit, University Hospital Vall d'Hebron, Passeig de la Vall d'Hebron 119, \\ 08035 Barcelona, Spain; teodora.pribic@gmail.com \\ 3 Centro de Investigación Biomédica en Red de Enfermedades Hepáticas y Digestivas (Ciberehd), Av. \\ Monforte de Lemos 3-5, 28029 Madrid, Spain \\ 4 Departament de Medicina, Universitat Autònoma de Barcelona, 08193 Cerdanyola del Vallès, Spain \\ * Correspondence: azpiroz.fernando@gmail.com; Tel.: +34-93-274-6222; Fax: +34-93-489-4456
}

Received: 2 March 2020; Accepted: 30 March 2020; Published: 2 April 2020

\begin{abstract}
Food ingestion induces a metered response of the digestive system. Initially, the upper digestive system reacts to process and extract meal substrates. Later, meal residues not absorbed in the small bowel, pass into the colon and activate the metabolism of resident microbiota. Food consumption also induces sensations that arise before ingestion (e.g., anticipatory reward), during ingestion (e.g., gustation), and most importantly, after the meal (i.e., the postprandial experience). The postprandial experience involves homeostatic sensations (satiety, fullness) with a hedonic dimension (digestive well-being, mood). The factors that determine the postprandial experience are poorly understood, despite their potential role in personalized diets and healthy eating habits. Current data suggest that the characteristics of the meal (amount, palatability, composition), the activity of the digestive system (suited processing), and the receptivity of the eater (influenced by multiple conditioning factors) may be important in this context.
\end{abstract}

Keywords: food ingestion; digestion; satiety; digestive well-being

\section{Introduction}

The importance of a healthy diet is well recognized, but to become acceptable, a diet needs to be attractive and gratifying. In this regard, it is crucial to understand the factors that determine the responses to ingested food and in particular the lasting effects following ingestion, i.e., the postprandial experience. In this context, the Nutrients Special Issue entitled Food and Diet for Gut Function and Dysfunction focuses on the role of the responses of the digestive system to food ingestion in normal conditions and in the disease state. The aim of the present paper is to provide an introductory overview to the Special Issue, outlining the effects of food ingestion on the brain-gut axis, i.e., the relations between digestive responses and the sensory experience. Purposely, this review is sketchy and descriptive; most of the experimental factual/information is provided in the different articles that compose the Special Issue. A comprehensive review on this subject, analyzing the relations between gastronomy and neurogastroenterology, has been previously published [1].

\section{Physiological Responses to Meal Ingestion}

During fasting, the gastrointestinal tract exerts a cyclic activity, alternating between periods of quiescence and periods of intense motor and secretory activity. The function of this stereotyped pattern, known as the migrating motor complex (MMC), appears to be the propulsion of residues from the lumen of the small intestine into the colon; thus, it is considered to be the intestinal housekeeper [2].

With the initiation of a meal, the digestive system is stimulated leading to the suppression of the interdigestive motor pattern and the activation of the digestive process. The digestive process 
involves three semi-sequential phases that overlap over time: cephalic, luminal, and post-absorptive. The cephalic phase refers to events before and during the ingestion period. Indeed, even before ingestion, the digestive system starts with a series of preparatory procedures, associated in normal conditions with an anticipatory reward sensation, e.g., anticipation of a desired meal stimulates salivary and gastric secretion. Food ingestion and swallowing activate oropharyngeal and oesophagogastric responses (salivation, oesophageal peristalsis, and gastric receptive relaxation). The walls of the stomach are contracted and virtually collapsed during fasting and meal arrival into the stomach induces an active relaxation (gastric accommodation). Solid particles activate the antral pump with peristaltic activity, which starts a grinding process that transforms the meal into a liquid chime. A gradual re-contraction of the stomach during the postprandial phase pushes the chime into the small bowel [3]. The activity of the stomach and small bowel adapts to the requirements of the digestive process, so that, food is digested and subsequently absorbed by a sequence of complex physical and chemical processes that begin in the mouth and extend to the terminal ileum. Ultimately, non-absorbed residues reach the colon [4]; these dietary residues serve as substrates for gut microbiota, and in return, the gut microbiota can affect host physiology and digestive function (Figure 1).

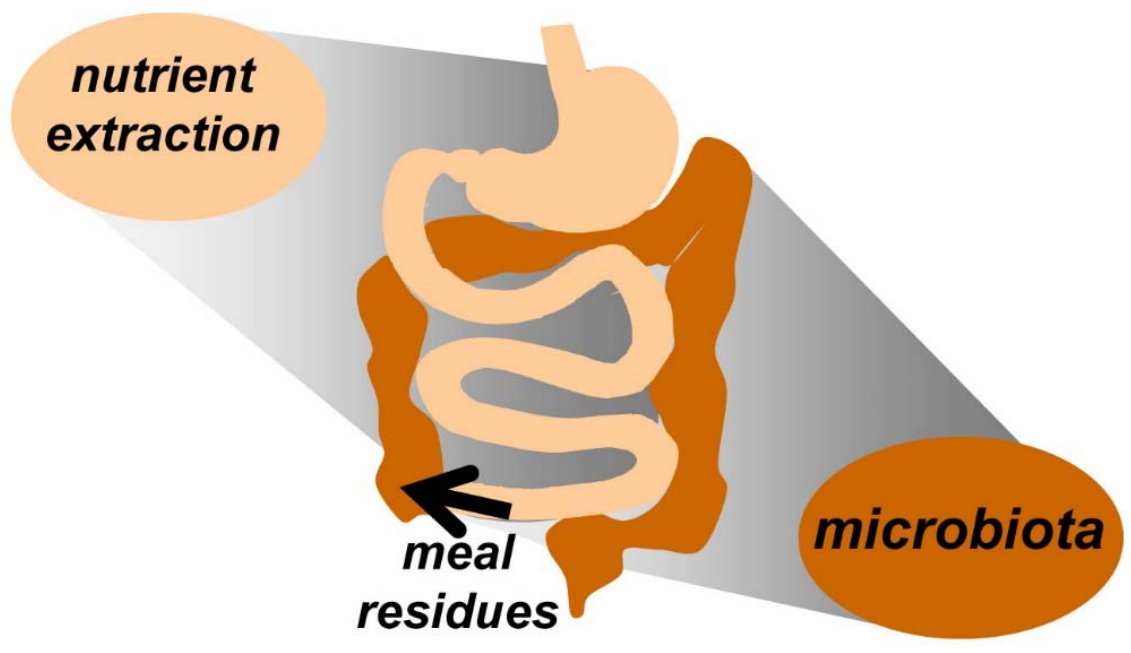

Figure 1. Digestive response to ingestion. The upper digestive system extracts meal substrates by a process of digestion and absorption. Non-absorbed meal residues pass into the colon and feed the microbiota.

Indeed, the large majority of human microbiota inhabit the colon, which provides a dedicated niche for this population of symbiotic organisms. Microbiota fermentation of meal residues releases a series of metabolites that, in turn, serve as substrates for other subsets of microbiota. Hence, the colon contains a biomass formed by microbiota, meal residues, and secondary metabolic products in a dynamic chain of metabolic reactions. The total volume of colonic biomass consists of approximately 500-800 $\mathrm{mL}$ with a $30 \%$ daily turnover (100-200 mL daily fecal output) [5]. Microbiota metabolism of some meal residues releases gas; hence, colonic gas production reflects microbiota metabolic activity [6]. Approximately 100 min after ingestion, unabsorbed residues start arriving into the colon, and gas production increases. The plateau lasts approximately 4-6 $\mathrm{h}$ depending on the meal composition and then gradually declines [7], but the effect persists as long as substrates remain available, such that the residue loads of consecutive meals contribute to gas production [8]. The volume of gas produced within $6 \mathrm{~h}$ after a meal ranges from $200 \mathrm{~mL}$ with a standard breakfast to $600 \mathrm{~mL}$ with a flatulogenic meal [7].

The activity of the muscles of the abdominal and thoracic walls depends on its content. Specifically, an increase in intraabdominal volume induces an adaptive relaxation of the diaphragm, which allows orad expansion of the abdominal cavity with compensatory contraction of the anterior abdominal wall; this somatic response prevents an increment in abdominal girth. The same adaptive response is triggered by ingestion of a meal, a phenomenon termed abdominal accommodation [9]. The extent of accommodation depends on the volume load. This somatic reflex has clinical relevance, 
because impaired abdominal accommodation produces abdominal distension, a frequent complaint in clinical practice; in these patients, an abnormal contraction of the diaphragm pushes abdominal content with protrusion of the anterior abdominal wall [10]. Physiologic changes in blood pressure, heart rate, blood flow in the superior mesenteric artery, and mesenteric vascular resistance, as well as in thermogenesis are also induced during the luminal and post-absorptive phase of digestion, but the specific meal-derived signals that control these responses are incompletely understood [11].

\section{Food Ingestion and the Brain-Gut Axis}

The entire digestive-absorptive process is finely regulated by a complex net of neuro-humoral feedback mechanisms, by which the gut is able to sense and react to intraluminal stimuli [4]. These reflex pathways are distributed within the autonomic and the enteric nervous system. This physiological configuration allows the gut to be highly versatile and adaptable. Stimuli in the gut may also activate afferent brain pathways, so that in addition to the digestive responses, meal consumption also induces sensory experiences that influence the control of food consumption and homeostasis (e.g., fullness and satiety) [12-17]. These sensory experiences are associated with pleasant or occasionally unpleasant sensations (changes in mood and digestive well-being), i.e., the hedonic dimension of the sensory experience [12-14,18,19]. Changes in the activity of the central nervous system (CNS) in response to meal ingestion have been documented by means of functional brain imaging (e.g., functional magnetic resonance imaging and positron emission tomography) [20-26]. These studies reveal the crucial role of the CNS in the control of food intake and the conscious perception of sensation and in the maintenance of homeostasis [27]. Meal ingestion is associated with changes in the blood levels of several compounds [13,28-30]. These compounds may be derived directly from the food (e.g., amino acids, lipids, and glucose), produced by the organism in response to the meal (e.g., hormones and neuropeptides) or may be the result of the metabolism of non-absorbed residues by the colonic microbiota [31,32]. The bidirectional interaction between the mind and the digestive system, involving both neural and humoral pathways is known as the brain-gut (or gut-brain) axis. There is a dynamic cross-talk between host and microbiota, the messengers and circuits are poorly understood, but metabolites derived from microbiota activity may play a role [33]. Attending to the role of microbiota, the concept has been extended to encompass the microbiota-gut-brain axis.

\section{Sensations before and during Food Ingestion}

The biological response to food is complex and involves events before, during, and after the meal. Indeed, the sensory experience related to meals starts before the ingestion period [34]. The anticipatory experience before the meal depends on factors related to the meal (e.g., meal appearance, smell), as well as the subject's homeostatic status (e.g., degree of hunger) and cognitive state (e.g., expectations).

Appetite is an imprecise term, since it may refer to differing concepts. It can be used as an all-inclusive term to cover all aspects of food intake, preference, motivation, and selection, or as a reference to the sensory and qualitative aspects of eating and the responsiveness to environmental stimulation [16]. Thus, the concept of "meal wanting" was coined in order to describe the pre-ingestive response to a specific food, i.e., the desire to eat that particular product $[35,36]$.

The motivational aspect of food consumption has been the subject of numerous studies [18,37-40]. The homeostatic regulation of eating depends on the degree of hunger (or satiation). Food ingestion reduces hunger sensation and depending on the amount ingested, induces satiation and fullness sensations; in principle satiation is a signal to stop ingestion. Remarkably, satiation is taste-specific, thus food diversity increases meal consumption. In any case, with increasing satiety and fullness, "meal wanting" and the desire to eat a food of choice decrease. The homeostatic regulation of food ingestion might be overruled by other factors such as the hedonic drive; this may lead to excessive eating and it has been associated with obesity and eating disorders [41,42]. Cognitive factors and the habits of the subject also play an important role. These include memories, beliefs, expectations, and thoughts related to what the subject considers about (a) the characteristics of the meal (satiating capacity, quality, health 
properties); (b) meal availability, either present and/or in the near future; (c) what the eater believes is beneficial or necessary at a certain moment (e.g., low-fat food for an obese patient). Notwithstanding, a decisive factor on food consumption is, at the end, what is present in the menu or in the plate, and thus, the importance of the serving portions in food consumption.

The most important aspects of food that can be detected by the senses (organoleptic properties) are taste, smell, and texture, although other properties, such as temperature, sound, and appearance, are also involved. The biology and physiologic mechanisms of food sensation have been thoroughly studied [43-46]. For the purpose of this review, three concepts in this regard will be considered: taste, flavor, and palatability

\subsection{Taste}

The taste perception, or in other words gustation, is triggered by the stimulation of specific receptors in the mouth and in the pharynx by molecules in a liquid environment. The five tastes that are widely accepted to play a major role in the experience of sensing food are: salty, sour, umami, bitter, and sweet. However, many additional tastes ( 20) including fatty acid, metallic, and electric have been proposed as candidates $[47,48]$. Nevertheless, the specific receptors involved in sensing each taste are still not fully understood. Moreover, the distribution and number of taste buds may differ in different persons as shown by the extreme sensitivity to bitter taste secondary to increased number of taste buds in up to $25 \%$ of the population, these individuals can be considered as supertasters [49,50]. Interestingly, taste receptors similar to those responsible for food sensing in the mouth have been identified along the gastrointestinal tract; their function appears to be related to regulation of gut function and homeostasis independent form taste sensation [3,51-54].

\subsection{Flavor}

Flavor is a complex and multi-modal sensory experience that occurs during food tasting [43] and directly involves gustatory and olfactory sensations [55]. However other senses, such as proprioception, temperature, vision, and sound, can impact flavor perception. Consequently, flavor is a combined interoceptive and exteroceptive experience.

The hot sensation in spices (pungency) is produced by capsaicin and other chemical components. These molecules are not sensed by taste receptors, but by sensory nerve endings analogous to those signaling pain, and the sensation is driven by the trigeminal nerves. Pungency is an important aspect in the flavor of food.

Olfaction, i.e., the perception of smell, deeply interacts with and enhances the perception of taste. The process of olfaction involves the orthonasal and retronasal systems. The former is activated by inhaling volatile compounds that enter the nose via the nostrils, while the latter is activated by volatile compounds released from the food during chewing and swallowing that reach the retronasal system through the posterior nares when the individual exhales. Sensory inputs form the anterior and posterior nasal systems are transmitted through different neural pathways to different brain areas. There are roughly 500 types of odorant receptors in the nasal mucosa [56-58]. Certain molecules activate several types of receptors, while each receptor type may be activated by different molecules. Thus, the precise odor of a product depends on the mixture of activated receptors.

Food temperature influences taste since it regulates the access of molecules from volatile compounds to sensing receptors. Moreover, in some individuals, sweet, sour, bitter, or salty sensations can be evoked by the application of heat to different parts of the tongue; a characteristic known as "thermal taster".

Food texture is perceived by touch and proprioception and depends on the rheological properties of the meal (i.e., flow of matter/changes in matter in response to applied force). Important hints to the texture of the meal are obtained before ingestion by physical manipulation (cutting, touching, mixing), vision, and occasionally by sound. During the oral phase, the feel of the food (mouth feel) is sensed by mastication and tongue shearing. Also, the sound that food makes within the mouth (e.g., crispy 
fries or crunchy crackers) is important for flavor sensing. There is an almost endless combination of textures that can be present in a meal (e.g., elasticity, consistency, astringency, viscosity, granularity, smoothness, sogginess, etc.).

Food appearance is an important factor that shapes the expectations related to flavor. Indeed, in a very interesting study, experimental mismatch of color in fruit-flavored beverages and candies was associated with incorrect identification of the product, (e.g., a yellow candy tends to be recognized as lemon flavor regardless of the true taste) [59]. It should be noted that mastication, salivation, and tongue movement change the rheological properties of food and molecules activating taste and smell are widely spread in the oral and retronasal cavities. Hence, the oral phase of digestion modifies the interoceptive properties of food that determine flavor (taste, odor, texture, pungency, and temperature).

\subsection{Palatability}

Palatability it is not a characteristic of the food itself, but rather it refers to the hedonic sensation (pleasurable or aversive) derived from food tasting (i.e., how good the food is perceived) [60]. It depends on the organoleptic properties of the meal, but more importantly on the receptiveness of the eater: the state of the eater before the meal (e.g., hunger), flavor perception, and interpretation [61,62]. Consequently, the palatability of the meal is dynamic and it changes during ingestion (palatability decreases as hunger decays and satiation arises). Subject attentiveness also plays an important role, e.g., palatability is more pronounced when the subject is paying attention to the meal than when distracted. The notion of "meal liking", in contrast to "meal wanting", reflects the hedonic dimension of the gustatory experience, i.e., palatability, but it extends further to include the postprandial sensation of satisfaction and digestive well-being [35]. Previous experience and memory influence palatability, such that more palatability is associated to flavors that are congruent and recognized. Conversely, exposure to an unfamiliar or aversive flavor can translate into a decrease in palatability [46]; however, in special situations (e.g., dinner in a special restaurant) the receptivity of the subject is increased and an unrecognized, unexpected, or incongruent gustatory experience (e.g., cold soup, salty ice cream) may increase the palatability of the meal by the surprise factor.

\section{The Postprandial Experience}

The sensations that arise during the time of ingestion extend into the postprandial period. Hence, the postprandial experience comprises homeostatic sensations (satiation, fullness) and hedonic sensations (i.e., post-prandial mood and digestive well-being) (Figure 2).

Homeostatic and hedonic sensations are not dependent on each other and experimental data in humans suggests that they are mediated by different mechanisms [27]. Indeed, when measured by analogue scales, hedonic and homeostatic responses, correlate with specific changes in brain activity and circulating metabolites [14,20,27]. Moreover, the hedonic response to postprandial fullness and/or satiety may be positive or negative in response to several conditions (see next section).

The postprandial experience is dynamic: hedonic and homeostatic sensations are more powerful in the immediate post-ingestion period and weaken progressively during the postprandial period. While, the term satiation refers to the sensation perceived during ingestion, the term satiety refers to the sensation perceived after the meal. Yet, the distinction between satiation and satiety is not completely supported by biological evidence and linguistically, this difference is not present in many languages. Satiation gradually decays during the postprandial state and regulates the inter-meal interval. Hence, by the end of the digestive process, subjects experience hunger again as a physiologic sign for the next meal. The type and amount of food that were consumed will have an important influence in the rate of decline in satiety and subsequently reappearance of hunger sensation. Furthermore, throughout the digestive process, additional sensations secondary to autonomic activity, e.g., warmth and sleepiness, appear. One to two hours after the meal, when undigested residues arrive into the colon and are fermented by the microbiota, sensations related to gas, such as flatulence and borborygmi, may arise, particularly after high flatulogenic meal (meals rich in non-absorbable, fermentable residues). 


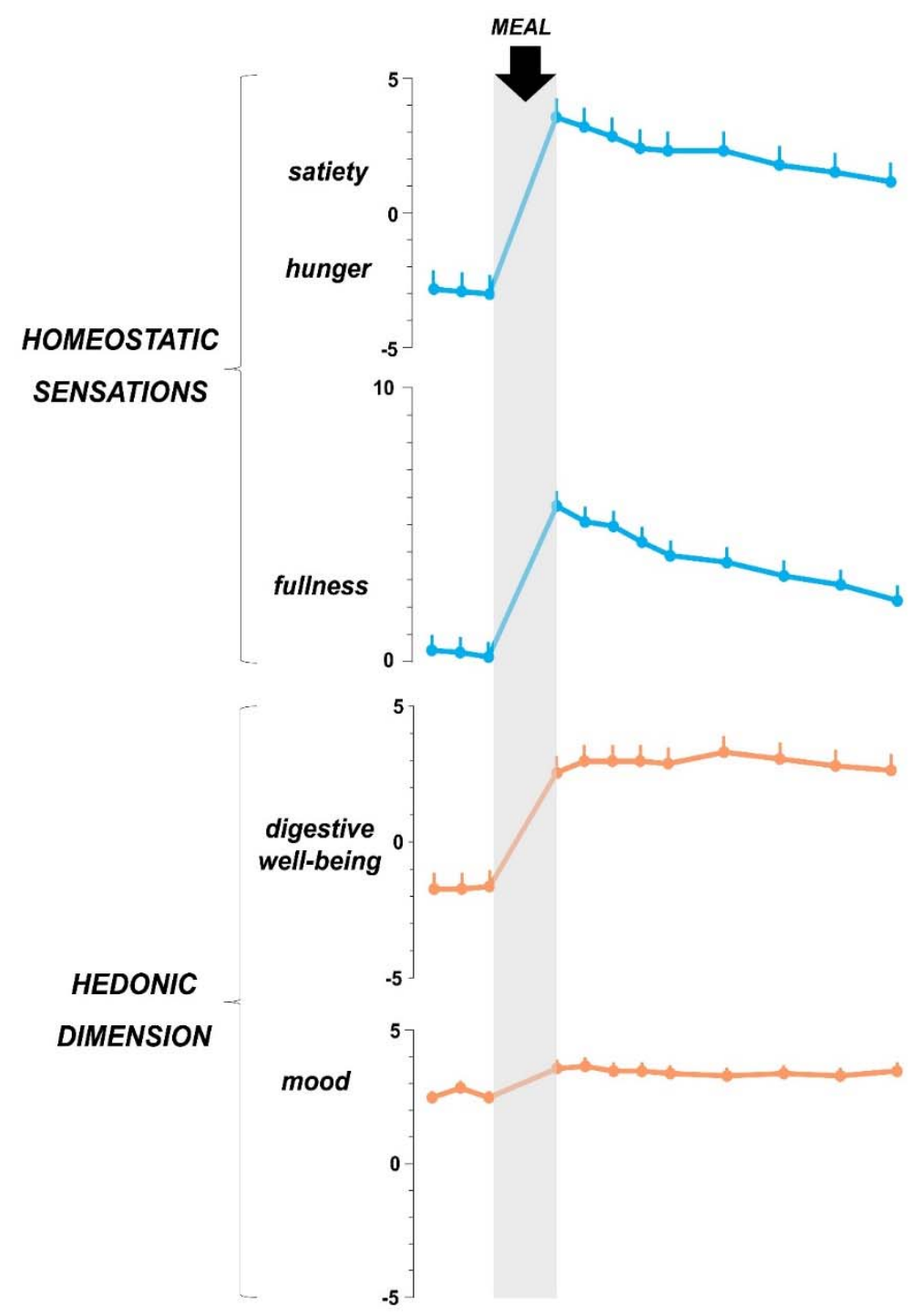

Figure 2. Sensations related to food ingestion. In healthy women $(n=12)$ a. palatable comfort meal induced homeostatic sensations (satiety, fullness) with pleasant hedonic dimension (increased digestive well-being and mood). Data from reference 79.

The postprandial experience depends on interacting factors related to (a) the digestive function, (b) the characteristics of the meal, and (c) the individual's responsiveness (Table 1 and Figure 3). 
Table 1. Factors that influence the postprandial experience: previous studies.

\begin{tabular}{|c|c|c|c|c|c|c|}
\hline Reference & $\begin{array}{l}\text { Design and } \\
\text { Outcomes }\end{array}$ & Aim & Participants & Interventions & Main Results & Conclusions \\
\hline $\begin{array}{l}\text { Malagelada et al., } \\
2015 \text { [12] }\end{array}$ & $\begin{array}{c}\text { Randomized, } \\
\text { crossover trial } \\
\text { Responses to test } \\
\text { meal (a) sensations by } \\
\text { scales (b) gastric tone } \\
\text { by barostat }\end{array}$ & $\begin{array}{l}\text { Effect of digestive } \\
\text { function on } \\
\text { perception }\end{array}$ & $\begin{array}{c}\text { Healthy } \\
\text { volunteers: } 25 \\
\text { women } 17 \text { men }\end{array}$ & $\begin{array}{l}\text { Distortion of digestive } \\
\text { function by gastric } \\
\text { distention or duodenal } \\
\text { lipids }\end{array}$ & $\begin{array}{l}\text { Experimental distortion of } \\
\text { digestive function affects } \\
\text { independently homeostatic and } \\
\text { hedonic sensations after a meal }\end{array}$ & $\begin{array}{l}\text { The digestive function } \\
\text { determines the } \\
\text { postprandial experience; } \\
\text { homeostatic and hedonic } \\
\text { sensations are } \\
\text { independent }\end{array}$ \\
\hline $\begin{array}{l}\text { Malagelada et al., } \\
2016[13]\end{array}$ & $\begin{array}{l}\text { Open label study } \\
\text { Responses to test } \\
\text { meal (a) sensations by } \\
\text { scales (b) } \\
\text { metabolomic analysis }\end{array}$ & $\begin{array}{l}\text { Metabolomic } \\
\text { biomarkers of } \\
\text { postprandial } \\
\text { sensations }\end{array}$ & $\begin{array}{c}\text { Healthy } \\
\text { volunteers: } 9 \\
\text { women } 9 \text { men }\end{array}$ & $\begin{array}{l}\text { Ingestion of a test meal at } \\
\text { the rate of } 50 \mathrm{~mL} / \mathrm{min} \text { at } \\
\text { until maximum satiation }\end{array}$ & $\begin{array}{l}\text { (a) satiation correlated with } \\
\text { increase in glucose and valine; (b) } \\
\text { well-being and decrease in choice } \\
\text { eating correlated with increase in } \\
\text { triglycerides; (c) abdominal } \\
\text { discomfort inversely correlated } \\
\text { with increase in lipids }\end{array}$ & $\begin{array}{l}\text { Postprandial sensations } \\
\text { correlate with changes in } \\
\text { circulating metabolites }\end{array}$ \\
\hline Pribic et al., 2017 [20] & $\begin{array}{c}\text { Open label study } \\
\text { Responses to probe } \\
\text { meal (a) sensations by } \\
\text { scales (b) fMRI scans } \\
\text { before and after probe } \\
\text { meal }\end{array}$ & $\begin{array}{l}\text { Brain networks } \\
\text { related to } \\
\text { postprandial } \\
\text { sensations }\end{array}$ & 38 healthy males & $\begin{array}{l}\text { Probe meal on two days } \\
\text { with and without fMRI }\end{array}$ & $\begin{array}{l}\text { (a) sensations were similar with } \\
\text { and without fMRI; (b) Ingestion } \\
\text { was associated with increase in } \\
\text { thalamo-cortical connectivity } \\
\text { and decrease in insular-cortical } \\
\text { connectivity; (c) a larger decrease } \\
\text { in insular-anterior cingulate } \\
\text { cortex connectivity and was } \\
\text { associated with higher satiety, } \\
\text { fullness, and digestive well-being }\end{array}$ & $\begin{array}{l}\text { Postprandial sensations } \\
\text { correlate with changes in } \\
\text { brain connectivity } \\
\text { functional networks }\end{array}$ \\
\hline $\begin{array}{c}\text { DuBose et al., } 1980 \\
{[59]}\end{array}$ & $\begin{array}{l}\text { Open label study } \\
\text { Identification of } \\
\text { flavor of test foods }\end{array}$ & $\begin{array}{l}\text { Influence of food } \\
\text { color on flavor } \\
\text { perception }\end{array}$ & $\begin{array}{l}\text { Healthy } \\
\text { volunteers }\end{array}$ & $\begin{array}{l}\text { Test foods with colorants } \\
\text { and flavorants: (a) } \\
\text { masking of color; (b) } \\
\text { color-flavor incongruence } \\
\text { (e.g., green colored } \\
\text {-orange flavor). }\end{array}$ & $\begin{array}{l}\text { Color masking or distortion } \\
\text { impaired flavor identification }\end{array}$ & $\begin{array}{l}\text { Flavor perception is } \\
\text { influenced by color of } \\
\text { food }\end{array}$ \\
\hline $\begin{array}{c}\text { Monrroy et al., } 2019 \\
{[63]}\end{array}$ & $\begin{array}{l}\text { Randomized parallel } \\
\text { trial. Sensations in } \\
\text { response to comfort } \\
\text { meal by scales }\end{array}$ & $\begin{array}{l}\text { Role of gender on the } \\
\text { responses to a } \\
\text { comfort meal }\end{array}$ & $\begin{array}{c}\text { Healthy } \\
\text { volunteers: } 10 \\
\text { women } 10 \text { men }\end{array}$ & $\begin{array}{l}\text { Comfort meal ingested } \\
\text { stepwise until full } \\
\text { satiation }\end{array}$ & $\begin{array}{l}\text { In women the meal loads } \\
\text { required to achieve maximal } \\
\text { satisfaction and full satiation } \\
\text { were smaller than in men. Hence } \\
\text { women enjoyed and tolerated } \\
\text { smaller meal loads than men }\end{array}$ & $\begin{array}{l}\text { Gender is a constitutive } \\
\text { factor that determines the } \\
\text { meal experience }\end{array}$ \\
\hline
\end{tabular}


Table 1. Cont.

\begin{tabular}{|c|c|c|c|c|c|c|}
\hline Reference & $\begin{array}{l}\text { Design and } \\
\text { Outcomes }\end{array}$ & Aim & Participants & Interventions & Main Results & Conclusions \\
\hline $\begin{array}{c}\text { Pribic et al., } 2018 \\
{[64]}\end{array}$ & $\begin{array}{l}\text { Randomized } \\
\text { crossover trial. } \\
\text { Sensations in } \\
\text { response to test meals } \\
\text { by scales }\end{array}$ & $\begin{array}{l}\text { Effect of palatability } \\
\text { on postprandial } \\
\text { sensations }\end{array}$ & $\begin{array}{l}22 \text { healthy } \\
\text { men }\end{array}$ & $\begin{array}{l}2 \text { meals with identical } \\
\text { composition and physical } \\
\text { characteristics but different } \\
\text { palatability: (a) conventional } \\
\text { (potato cream followed by } \\
\text { vanilla cream); (b) } \\
\text { unconventional meal } \\
\text { (mixture of both creams). }\end{array}$ & $\begin{array}{l}\text { The unconventional was found } \\
\text { less palatable and meal produced } \\
\text { more fullness and less } \\
\text { satisfaction than the } \\
\text { conventional meal }\end{array}$ & $\begin{array}{c}\text { Food palatability bears a } \\
\text { direct relation to hedonic } \\
\text { but inverse relation to } \\
\text { homeostatic sensations. }\end{array}$ \\
\hline $\begin{array}{c}\text { Pribic et al., } 2018 \\
\text { [65] }\end{array}$ & $\begin{array}{l}\text { Randomized } \\
\text { crossover trial. } \\
\text { Sensations in } \\
\text { response to test meals } \\
\text { by scales }\end{array}$ & $\begin{array}{l}\text { Influence of meal } \\
\text { composition } \\
\text { independently of } \\
\text { palatability on } \\
\text { postprandial } \\
\text { sensations }\end{array}$ & $\begin{array}{l}12 \text { healthy } \\
\text { men }\end{array}$ & $\begin{array}{l}2 \text { meals with the same } \\
\text { physical and organoleptic } \\
\text { characteristics (taste, smell, } \\
\text { texture, color, and } \\
\text { temperature) but different } \\
\text { composition: (a) low-fat; (b) } \\
\text { high-fat test meal }\end{array}$ & $\begin{array}{l}\text { While palatability was similar, } \\
\text { the high-fat mal induced more } \\
\text { satisfaction than the low-fat meal, } \\
\text { without significant differences in } \\
\text { homeostatic sensations }\end{array}$ & $\begin{array}{c}\text { Meal composition } \\
\text { determines the } \\
\text { postprandial experience } \\
\text { independently of } \\
\text { palatability. }\end{array}$ \\
\hline $\begin{array}{c}\text { Masihy et al., } \\
2019 \text { [66] }\end{array}$ & $\begin{array}{l}\text { Randomized parallel } \\
\text { trial. Responses to } \\
\text { probe meal: (a) } \\
\text { sensations by scales } \\
\text { (b) physiological } \\
\text { measures }\end{array}$ & $\begin{array}{l}\text { Influence of eating } \\
\text { schedule on } \\
\text { postprandial } \\
\text { responses: gender } \\
\text { effects }\end{array}$ & $\begin{array}{l}\text { Healthy } \\
\text { volunteers: } 10 \\
\text { women } 10 \\
\text { men }\end{array}$ & $\begin{array}{l}\text { Lunch-type meal eaten at: (a) } \\
\text { habitual afternoon schedule; } \\
\text { (b) unconventional morning } \\
\text { schedule }\end{array}$ & $\begin{array}{l}\text { No schedule effect on } \\
\text { physiological responses to probe } \\
\text { meal in women and men were } \\
\text { detected. However, in contrast to } \\
\text { men, in women, the probe meal } \\
\text { at unconventional time induced } \\
\text { less satisfaction than at the } \\
\text { conventional time }\end{array}$ & $\begin{array}{l}\text { Women are more } \\
\text { susceptible to the } \\
\text { influence of eating } \\
\text { schedule on the } \\
\text { postprandial experience } \\
\text { than men. }\end{array}$ \\
\hline $\begin{array}{c}\text { Pribic et al., } 2017 \\
{[67]}\end{array}$ & $\begin{array}{l}\text { Randomized cross } \\
\text { over. Sensations in } \\
\text { response to test meals } \\
\text { by scales }\end{array}$ & $\begin{array}{l}\text { Influence of appetite } \\
\text { on postprandial } \\
\text { experience }\end{array}$ & $\begin{array}{l}12 \text { healthy } \\
\text { men }\end{array}$ & $\begin{array}{c}\text { Probe meal consumed two } \\
\text { hours after: (a) low-calorie } \\
\text { breakfast; (b) high-calorie } \\
\text { breakfast }\end{array}$ & $\begin{array}{l}\text { As compared to the low-calorie } \\
\text { breakfast, with the high-calorie } \\
\text { breakfast subjects were less } \\
\text { hungry before the probe meal } \\
\text { and experienced more } \\
\text { postprandial fullness and less } \\
\text { satisfaction }\end{array}$ & $\begin{array}{l}\text { Appetite before the meal } \\
\text { influences the } \\
\text { postprandial experience }\end{array}$ \\
\hline $\begin{array}{c}\text { Pribic et al., } 2018 \\
{[68]}\end{array}$ & $\begin{array}{l}\text { Randomized, parallel } \\
\text { study. Sensations in } \\
\text { response to probe } \\
\text { meal by scales. }\end{array}$ & $\begin{array}{l}\text { Influence of education } \\
\text { on postprandial } \\
\text { experience }\end{array}$ & $\begin{array}{l}\text { Healthy men: } \\
14 \text { per group }\end{array}$ & $\begin{array}{l}\text { Administration of probe } \\
\text { meal on } 2 \text { days without and } \\
\text { with prior educational } \\
\text { intervention. One group } \\
\text { received a sensory-cognitive } \\
\text { intervention and the other a } \\
\text { sham intervention }\end{array}$ & $\begin{array}{l}\text { The sensory-cognitive } \\
\text { intervention enhanced } \\
\text { homeostatic and hedonic } \\
\text { sensations after the probe meal, } \\
\text { whereas the sham intervention } \\
\text { had no effect }\end{array}$ & $\begin{array}{l}\text { The receptiveness of the } \\
\text { subject and the } \\
\text { postprandial experience } \\
\text { can be conditioned by } \\
\text { education }\end{array}$ \\
\hline
\end{tabular}




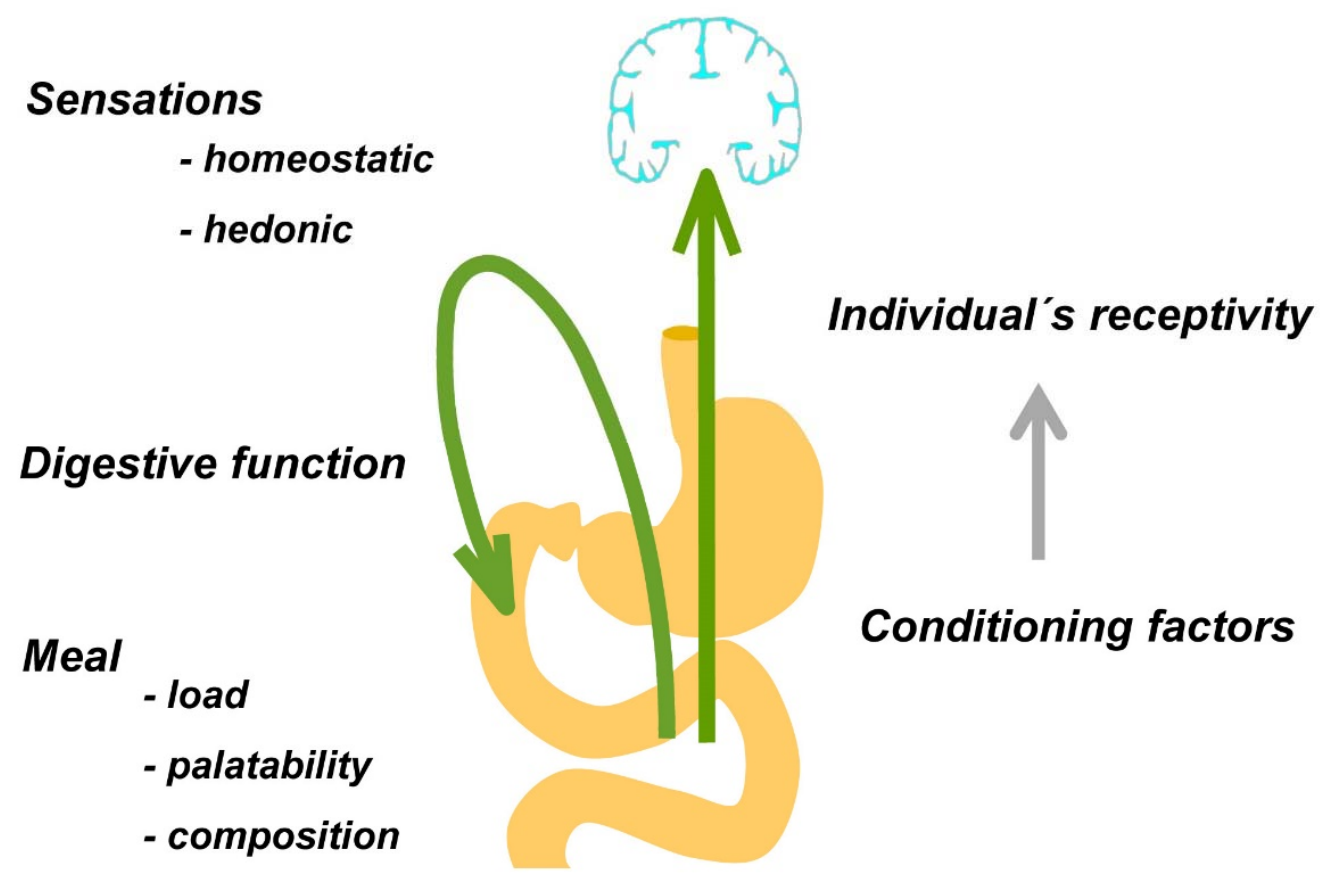

Figure 3. Biological responses to food ingestion. Meal ingestion induces digestive and sensory responses. Homeostatic (satiety, fullness) and hedonic sensations (digestive well-being and mood) depend on the characteristics of the meal, the digestive response, and the individual's receptivity, which can be influenced by multiple conditioning factors. Adapted from reference [1].

\subsection{Digestive Function}

The leading determinant of digestive sensations is the digestive function, so that a satisfactory postprandial experience depends on adequate digestive responses to a meal $[15,17,69,70]$. For example, this has been shown by disturbing gastric accommodation: inflation of a gastric balloon impairs the postprandial sensations [12]. Remarkably, patients with functional gut disorders show intestinal dysfunction and hypersensitivity so that the postprandial period after normal meals turns symptomatic. Nevertheless, the mechanism and specific food components that are responsible for the arousal of symptoms in these patients, or occasionally in healthy individuals, are incompletely understood. In healthy individuals, fat has a strong influence on digestive function; it induces satiety and fullness and enhances gut sensitivity. This response is augmented in patients with functional gut disorders and is related to their intolerance to fat ingestion [71,72]. Indeed, in functional dyspepsia and irritable bowel syndrome, fatty foods are the most common features of the meal that trigger symptoms [71,72].

\subsection{Characteristics of the Meal}

Many properties of the meal may influence the postprandial experience. Nevertheless, all are related to the meal load (i.e., amount of ingested food), palatability, and composition.

\subsubsection{Meal Load}

Obviously, homeostatic sensations depend on the amount of food consumed, with larger meals inducing more satiety and fullness. However, the relation of homeostatic and hedonic responses to a meal is bimodal depending on the meal load. Ingestion of a gratifying meal induces both satiety and satisfaction, i.e., homeostatic and hedonic sensations increase in parallel. Nevertheless, this is true up to a certain limit when the relation overturns and increasing meal loads still increase satiety but with a gradual decrease in digestive well-being; the nadir is reached with large meals at the point of full satiation, which induces a uncomfortable fullness sensation [63]. 


\subsubsection{Meal Palatability}

The central role of palatability in the postprandial experience was elegantly demonstrated by a recent study. Two meal courses where carefully prepared to have the same texture, consistency, temperature, and color, but with different palatability. The first one was a potato and cream cheese course and the second a vanilla cream dessert. Based on these courses, two different meals were prepared: a conventional meal was served by giving the first course as main dish and then the second as a dessert; an unconventional meal was served by mixing the two courses in a single dish, preserving the same physical characteristics of the two individual components. Indeed, both meals had the same composition and physical characteristics. Twenty-two healthy males were randomized in a cross-over design to receive the conventional meal and the unconventional meal on different days. The conventional meal was found palatable and induced a pleasant sensation. By contrast, participants found the unconventional meal unpalatable and reported higher fullness sensation with lower mood and digestive well-being [64].

\subsubsection{Meal Composition}

Despite the central role of palatability on the postprandial experience, other factors are also important. Indeed, appetizing and desirable meals may be followed by a negative, even symptomatic postprandial experience. Thus, in addition to palatably, some meal components may have an intrinsic effect in postprandial sensations and may produce symptoms by themselves. Therefore, the gustatory experience during ingestion (i.e., food taste and palatability) cannot forecast its postprandial effects, and even delicious meals may be followed by negative postprandial sensations.

The specific effects of particular meal components on postprandial sensations have not been properly described. Still, fat is the best described food component related to postprandial sensations. On the one hand, fatty "comfort" food in healthy individuals is associated with comfort and positive mood (reviewed in [19]); on the other hand, after a certain threshold, fat in excess decreases satisfaction and induces aversive sensation in the postprandial period [14,65]. It is plausible that intraluminal and post-absorptive mechanisms are behind the effects of meal composition on postprandial sensations. The influence of meal composition and meal-related signals on digestive function and perception has been specifically addressed in another paper of this Special Issue [73].

\subsection{The Individual's Receptivity}

The receptivity of the individual to the meal is determined by constitutive and inducible factors. In the first place, among constitutive factors, innate qualities are key to the postprandial experience. Recent proof-of-concept studies indicate that sex may play an important role, and showed that the response to the same meal is different in women and men. These studies showed that women enjoy and tolerate smaller meals than men, i.e., a meal that induces satisfactory satiety in men may induce aversive fullness sensation in women $[63,66,74]$. Conceivably, other constitutive characteristics may also play a role in the individual predisposition to respond to a meal, so that some individuals may be more gifted to appreciate and enjoy meals.

The receptivity of individuals depends also on inducible factors. Indeed, multiple conditioning factors may influence the postprandial experience. For instance, some studies have shown the role of homeostatic conditions, e.g., less hunger before ingestion results in more postprandial satiety and less satisfaction [67]. The habits of the individual are also important and, independently of hunger, influence the response to a meal: a meal consumed at an unconventional schedule induces more satiation and less satisfaction than at the right time, and interestingly, women are more susceptible to the eating schedule than men [66]. A study showed that cognitive/sensory conditioning by an educational intervention influences the postprandial experience: hedonic and homeostatic responses to the test meal, were both enhanced by the intervention [68], i.e., by an educational intervention the subjects learned to enjoy a test meal and experienced more satiation. The potential role of education 
in the modulation of the postprandial response may have important applications in different areas, including food consumption, acquisition of healthy habits, and in the treatment of digestive symptoms. Conceivably, the diner's status may be also influenced by a large variety of environmental factors.

\section{Conclusions}

The data presented in this review indicate, first, that the postprandial experience is a key aspect of the biological response to food ingestion, and second, that a number of factors may determine this response. These factors are related to the characteristics of food (specifically, amount, palatability, and composition), the function of the digestion system (e.g., an impaired digestive response hampers the postprandial experience), and the responsiveness of the eater, that depends on constitutive (e.g., sex) and inducible factors; the latter may be influenced by a myriad of conditioning stimuli. In order to enhance the gastronomic experience, not only the food, but also the eater requires preparation. Investigations on the role of education and conditioning in shaping the individual's receptivity may be the key to the development of healthy eating habits and the design of personalized diets.

Author Contributions: Review of the literature and manuscript revision, D.M.L.; review of the literature, T.P.; review of the literature and manuscript preparation, F.A. All authors have read and agreed to the published version of the manuscript.

Funding: This work was supported in part by the Spanish Ministry of Economy and Competitiveness (Dirección General de Investigación Científica y Técnica, SAF 2016-76648-R; CENIT program CEN-20101016; and Centro para el Desarrollo Tecnológico Industrial IDI20150103). Ciberehd is funded by the Instituto de Salud Carlos III. The research leading to these results has received funding from the People Programme of the EU's 7th Framework Programme under REA grant agreement no. 607652 (ITN NeuroGut).

Acknowledgments: The authors thank Gloria Santaliestra for secretarial assistance.

Conflicts of Interest: The authors declare no conflict of interest.

\section{References}

1. Pribic, T.; Azpiroz, F. Biogastronomy: Factors that determine the biological response to meal ingestion. Neurogastroenterol. Motil. 2018, 30, e13309. [CrossRef] [PubMed]

2. Deloose, E.; Tack, J. Redefining the functional roles of the gastrointestinal migrating motor complex and motilin in small bacterial overgrowth and hunger signaling. Am. J. Physiol. Gastrointest. Liver Physiol. 2016, 310, G228-G233. [CrossRef] [PubMed]

3. Azpiroz, F.; Feinle, C.; Grundy, D.; Tack, J. Gastric sensitivity and reflexes: Basic mechanism underlying clinical problems. J. Gastroenterol. 2014, 49, 206-218. [CrossRef] [PubMed]

4. Boeckxstaens, G.; Camilleri, M.; Sifrim, D.; Houghton, L.A.; Elsenbruch, S.; Lindberg, G.; Azpiroz, F.; Parkman, H.P. Fundamentals of Neurogastroenterology: Physiology/Motility-Sensation. Gastroenterology 2016, 150, 1292-1304. [CrossRef] [PubMed]

5. Bendezu, R.A.; Mego, M.; Monclus, E.; Merino, X.; Accarino, A.; Malagelada, J.R.; Navazo, I.; Azpiroz, F. Colonic content: Effect of diet, meals, and defecation. Neurogastroenterol. Motil. 2017, 29, e12930. [CrossRef]

6. Azpiroz, F. Intestinal gas. In Pathophysiology, Diagnosis, Management, 10th ed.; Feldman, M., Friedman, L.S., Brand, L.J., Eds.; Elsevier: Philadelphia, PA, USA, 2015; pp. 242-250.

7. Manichanh, C.; Eck, A.; Varela, E.; Roca, J.; Clemente, J.C.; Gonzalez, A.; Knights, D.; Knight, R.; Estrella, S.; Hernandez, C.; et al. Anal gas evacuation and colonic microbiota in patients with flatulence: Effect of diet. Gut 2013, 63, 401-408. [CrossRef]

8. Mego, M.; Accarino, A.; Malagelada, J.R.; Guarner, F.; Azpiroz, F. Accumulative effect of food residues on intestinal gas production. Neurogastroenterol. Motil. 2015, 27, 1621-1628. [CrossRef]

9. Burri, E.; Cisternas, D.; Villoria, A.; Accarino, A.; Soldevilla, A.; Malagelada, J.R.; Azpiroz, F. Abdominal accommodation induced by meal ingestion: Differential responses to gastric and colonic volume loads. Neurogastroenterol. Mot. 2013, 25, 339-e253. [CrossRef]

10. Burri, E.; Barba, E.; Huaman, J.W.; Cisternas, D.; Accarino, A.; Soldevilla, A.; Malagelada, J.R.; Azpiroz, F. Mechanisms of postprandial abdominal bloating and distension in functional dyspepsia. Gut 2014, 63, 395-400. [CrossRef] 
11. Vanis, L.; Gentilcore, D.; Lange, K.; Gilja, O.H.; Rigda, R.S.; Trahair, L.G.; Feinle-Bisset, C.; Rayner, C.K.; Horowitz, M.; Jones, K.L. Effects of variations in intragastric volume on blood pressure and splanchnic blood flow during intraduodenal glucose infusion in healthy older subjects. Am. J. Physiol. Regul. Integr. Comp. Physiol. 2012, 302, R391-R399. [CrossRef]

12. Malagelada, C.; Accarino, A.; Molne, L.; Mendez, S.; Campos, E.; Gonzalez, A.; Malagelada, J.R.; Azpiroz, F. Digestive, cognitive and hedonic responses to a meal. Neurogastroenterol. Motil. 2015, 27, 389-396. [CrossRef]

13. Malagelada, C.; Barba, I.; Accarino, A.; Molne, L.; Mendez, S.; Campos, E.; Gonzalez, A.; Alonso-Cotoner, C.; Santos, J.; Malagelada, J.R.; et al. Cognitive and hedonic responses to meal ingestion correlate with changes in circulating metabolites. Neurogastroenterol. Motil. 2016, 28, 1806-1814. [CrossRef]

14. Ciccantelli, B.; Pribic, T.; Malagelada, C.; Accarino, A.; Azpiroz, F. Relation between cognitive and hedonic responses to a meal. Neurogastroenterol. Motil. 2017, 29, e13011. [CrossRef]

15. Camilleri, M. Peripheral mechanisms in appetite regulation. Gastroenterology 2015, 148, 1219-1233. [CrossRef]

16. Blundell, J.; de Graaf, C.; Hulshof, T.; Jebb, S.; Livingstone, B.; Lluch, A.; Mela, D.; Salah, S.; Schuring, E.; van der Knaap, H.; et al. Appetite control: Methodological aspects of the evaluation of foods. Obes. Rev. 2010, 11, 251-270. [CrossRef]

17. Feinle-Bisset, C. Upper gastrointestinal sensitivity to meal-related signals in adult humans-Relevance to appetite regulation and gut symptoms in health, obesity and functional dyspepsia. Physiol. Behav. 2016, 162, 69-82. [CrossRef] [PubMed]

18. Egecioglu, E.; Skibicka, K.P.; Hansson, C.; Alvarez-Crespo, M.; Friberg, P.A.; Jerlhag, E.; Engel, J.A.; Dickson, S.L. Hedonic and incentive signals for body weight control. Rev. Endocr. Metab. Disord. 2011, 12, 141-151. [CrossRef] [PubMed]

19. Weltens, N.; Zhao, D.; Van Oudenhove, L. Where is the comfort in comfort foods? Mechanisms linking fat signaling, reward, and emotion. Neurogastroenterol Motil. 2014, 26, 303-315. [CrossRef] [PubMed]

20. Pribic, T.; Kilpatrick, L.; Ciccantelli, B.; Malagelada, C.; Accarino, A.; Rovira, A.; Pareto, D.; Mayer, E.; Azpiroz, F. Brain networks associated with cognitive and hedonic responses to a meal. Neurogastroenterol. Motil. 2017, 29, e13031. [CrossRef] [PubMed]

21. Li, J.; An, R.; Zhang, Y.; Li, X.; Wang, S. Correlations of macronutrient-induced functional magnetic resonance imaging signal changes in human brain and gut hormone responses. Am. J. Clin. Nutr. 2012, 96, 275-282. [CrossRef]

22. Page, K.A.; Chan, O.; Arora, J.; Belfort-Deaguiar, R.; Dzuira, J.; Roehmholdt, B.; Cline, G.W.; Naik, S.; Sinha, R.; Constable, R.T.; et al. Effects of fructose vs glucose on regional cerebral blood flow in brain regions involved with appetite and reward pathways. JAMA 2013, 309, 63-70. [CrossRef] [PubMed]

23. Frank, S.; Linder, K.; Kullmann, S.; Heni, M.; Ketterer, C.; Cavusoglu, M.; Krzeminski, A.; Fritsche, A.; Häring, H.U.; Preissl, H.; et al. Fat intake modulates cerebral blood flow in homeostatic and gustatory brain areas in humans. Am. J. Clin. Nutr. 2012, 95, 1342-1349. [CrossRef] [PubMed]

24. Francis, S.T.; Eldeghaidy, S. Imaging methodologies and applications for nutrition research: What can functional MRI offer? Proc. Nutr. Soc. 2015, 74, 89-98. [CrossRef] [PubMed]

25. Lee, I.S.; Preissl, H.; Enck, P. How to Perform and Interpret Functional Magnetic Resonance Imaging Studies in Functional Gastrointestinal Disorders. J. Neurogastroenterol. Motil. 2017, 23, 197-207. [CrossRef]

26. Ly, H.G.; Dupont, P.; Van Laere, K.; Depoortere, I.; Tack, J.; Van Oudenhove, L. Differential brain responses to gradual intragastric nutrient infusion and gastric balloon distension: A role for gut peptides? Neuroimage 2017, 144, 101-112. [CrossRef]

27. Simon, J.J.; Wetzel, A.; Sinno, M.H.; Skunde, M.; Bendszus, M.; Preissl, H.; Enck, P.; Herzog, W.; Friederich, H.C. Integration of homeostatic signaling and food reward processing in the human brain. JCI Insight 2017, 2. [CrossRef]

28. Zanchi, D.; Depoorter, A.; Egloff, L.; Haller, S.; Mahlmann, L.; Lang, U.E.; Drewe, J.; Beglinger, C.; Schmidt, A.; Borgwardt, S. The impact of gut hormones on the neural circuit of appetite and satiety: A systematic review. Neurosci. Biobehav. Rev. 2017, 80, 457-475. [CrossRef]

29. Astarita, G.; Langridge, J. An emerging role for metabolomics in nutrition science. J. Nutr. Nutr. 2013, 6, 181-200. [CrossRef]

30. Bondia-Pons, I.; Canellas, N.; Abete, I.; Rodriguez, M.A.; Perez-Cornago, A.; Navas-Carretero, S.; Zulet, M.A.; Correig, X.; Martínez, J.A. Nutri-metabolomics: Subtle serum metabolic differences in healthy subjects 
by NMR-based metabolomics after a short-term nutritional intervention with two tomato sauces. Omics 2013, 17, 611-618. [CrossRef]

31. De Vadder, F.; Kovatcheva-Datchary, P.; Goncalves, D.; Vinera, J.; Zitoun, C.; Duchampt, A.; Bäckhed, A.; Mithieux, G. Microbiota-generated metabolites promote metabolic benefits via gut-brain neural circuits. Cell 2014, 156, 84-96. [CrossRef]

32. Lyte, M. Microbial endocrinology: Host-microbiota neuroendocrine interactions influencing brain and behavior. Gut Microbes. 2014, 5, 381-389. [CrossRef]

33. Mayer, E.A.; Hsiao, E.Y. The Gut and Its Microbiome as Related to Central Nervous System Functioning and Psychological Well-being: Introduction to the Special Issue of Psychosomatic Medicine. Psychosom. Med. 2017, 79, 844-846. [CrossRef]

34. Smeets, P.A.; Erkner, A.; De Graaf, C. Cephalic phase responses and appetite. Nutr. Rev. 2010, 68, $643-655$. [CrossRef]

35. Berridge, K.C. 'Liking' and 'wanting' food rewards: Brain substrates and roles in eating disorders. Physiol. Behav. 2009, 97, 537-550. [CrossRef]

36. Finlayson, G.; King, N.; Blundell, J. The role of implicit wanting in relation to explicit liking and wanting for food: Implications for appetite control. Appetite 2008, 50, 120-127. [CrossRef]

37. Phan, U.T.; Chambers, E.T. Motivations for choosing various food groups based on individual foods. Appetite 2016, 105, 204-211. [CrossRef]

38. Mela, D.J. Determinants of food choice: Relationships with obesity and weight control. Obes. Res. 2001, 9, 249S-255S. [CrossRef]

39. Mela, D.J. Eating for pleasure or just wanting to eat? Reconsidering sensory hedonic responses as a driver of obesity. Appetite 2006, 47, 10-17. [CrossRef]

40. Lutter, M.; Nestler, E.J. Homeostatic and hedonic signals interact in the regulation of food intake. J. Nutr. 2009, 139, 629-632. [CrossRef]

41. Schultes, B.; Ernst, B.; Wilms, B.; Thurnheer, M.; Hallschmid, M. Hedonic hunger is increased in severely obese patients and is reduced after gastric bypass surgery. Am. J. Clin. Nutr. 2010, 92, 277-283. [CrossRef]

42. Witt, A.A.; Lowe, M.R. Hedonic hunger and binge eating among women with eating disorders. Int. J. Eat. Disord. 2014, 47, 273-280. [CrossRef]

43. Small, D.M. Flavor is in the brain. Physiol. Behav. 2012, 107, 540-552. [CrossRef]

44. Auvray, M.; Spence, C. The multisensory perception of flavor. Conscious. Cogn. 2008, 17, 1016-1031. [CrossRef]

45. Lindemann, B. Receptors and transduction in taste. Nature 2001, 413, 219-225. [CrossRef]

46. Pandurangan, M.; Hwang, I. Systemic mechanism of taste, flavour and palatability in brain. Appl. Biochem. Biotechnol. 2015, 175, 3133-3147. [CrossRef]

47. Chaudhari, N.; Roper, S.D. The cell biology of taste. J. Cell Biol. 2010, 190, 285-296. [CrossRef]

48. Lawless, H.T.; Stevens, D.A.; Chapman, K.W.; Kurtz, A. Metallic taste from electrical and chemical stimulation. Chem. Senses 2005, 30, 185-194. [CrossRef]

49. Reed, D.R. Birth of a new breed of supertaster. Chem. Senses 2008, 33, 489-491. [CrossRef]

50. Robino, A.; Mezzavilla, M.; Pirastu, N.; Dognini, M.; Tepper, B.J.; Gasparini, P. A population-based approach to study the impact of PROP perception on food liking in populations along the Silk Road. PLoS ONE 2014, 9, e91716. [CrossRef]

51. Deloose, E.; Corsetti, M.; Van Oudenhove, L.; Depoortere, I.; Tack, J. Intragastric infusion of the bitter tastant quinine suppresses hormone release and antral motility during the fasting state in healthy female volunteers. Neurogastroenterol. Motil. 2018, 30, e13171. [CrossRef]

52. Avau, B.; Rotondo, A.; Thijs, T.; Andrews, C.N.; Janssen, P.; Tack, J.; Depoortere, I. Targeting extra-oral bitter taste receptors modulates gastrointestinal motility with effects on satiation. Sci. Rep. 2015, 5, 15985. [CrossRef]

53. Cvijanovic, N.; Isaacs, N.J.; Rayner, C.K.; Feinle-Bisset, C.; Young, R.L.; Little, T.J. Lipid stimulation of fatty acid sensors in the human duodenum: Relationship with gastrointestinal hormones, BMI and diet. Int. J. Obes. 2017, 41, 233-239. [CrossRef]

54. Depoortere, I. Taste receptors of the gut: Emerging roles in health and disease. Gut 2014, 63, 179-190. [CrossRef] 
55. Delwiche, J. The impact of perceptual interactions on perceived flavor. Food Qual. Prefer. 2004, 15, 137-146. [CrossRef]

56. Doty, R.L. Olfaction. Annu. Rev. Psychol. 2001, 52, 423-452. [CrossRef]

57. Barham, P.; Skibsted, L.H.; Bredie, W.L.; Frost, M.B.; Moller, P.; Risbo, J.; Snitkjær, P.; Mortensen, L.M. Molecular gastronomy: A new emerging scientific discipline. Chem. Rev. 2010, 110, 2313-2365. [CrossRef]

58. Gilad, Y.; Lancet, D. Population differences in the human functional olfactory repertoire. Mol. Biol. Evol. 2003, 20, 307-314. [CrossRef]

59. DuBose, C.; Cardello, A.; Maller, O. Effects of colorants and flavorants on identification, perceived flavor intensity, and hedonic quality of fruit-flavored beverages and cake. J. Food Sci. 1980, 45, 1393-1399. [CrossRef]

60. Yeomans, M.R. Taste, palatability and the control of appetite. Proc. Nutr. Soc. 1998, 57, 609-615. [CrossRef]

61. Sauer, H.; Ohla, K.; Dammann, D.; Teufel, M.; Zipfel, S.; Enck, P.; Mack, I. Changes in Gustatory Function and Taste Preference Following Weight Loss. J. Pediatr. 2017, 182, 120-126. [CrossRef]

62. Sorensen, L.B.; Moller, P.; Flint, A.; Martens, M.; Raben, A. Effect of sensory perception of foods on appetite and food intake: A review of studies on humans. Int. J. Obes. Relat. Metab. Disord. 2003, 27, 1152-1166. [CrossRef]

63. Monrroy, H.; Pribic, T.; Galan, C.; Nieto, A.; Amigo, N.; Accarino, A.; Correig, X.; Azpiroz, F. Meal Enjoyment and Tolerance in Women and Men. Nutrients 2019, 11, 119. [CrossRef]

64. Pribic, T.; Hernandez, L.; Nieto, A.; Malagelada, C.; Accarino, A.; Azpiroz, F. Effects of meal palatability on postprandial sensations. Neurogastroenterol. Motil. 2018, 30, e13197. [CrossRef]

65. Pribic, T.; Vilaseca, H.; Nieto, A.; Hernandez, L.; Monrroy, H.; Malagelada, C.; Accarino, A.; Roca, J.; Azpiroz, F. Meal composition influences postprandial sensations independently of valence and gustation. Neurogastroenterol. Motil. 2018, 30, e13337. [CrossRef]

66. Masihy, M.; Monrroy, H.; Borghi, G.; Pribic, T.; Galan, C.; Nieto, A.; Accarino, A.; Azpiroz, F. Influence of Eating Schedule on the Postprandial Response: Gender Differences. Nutrients 2019, 11, 401. [CrossRef]

67. Pribic, T.; Nieto, A.; Hernandez, L.; Malagelada, C.; Accarino, A.; Azpiroz, F. Appetite influences the responses to meal ingestion. Neurogastroenterol. Motil. 2017, 29. [CrossRef]

68. Pribic, T.; Vilaseca, H.; Nieto, A.; Hernandez, L.; Malagelada, C.; Accarino, A.; Roca, J.; Azpiroz, F. Education of the postprandial experience by a sensory-cognitive intervention. Neurogastroenterol. Motil. 2018, 30. [CrossRef]

69. Tack, J.; Deloose, E.; Ang, D.; Scarpellini, E.; Vanuytsel, T.; Van Oudenhove, L.; Depoortere, I. Motilin-induced gastric contractions signal hunger in man. Gut 2016, 65, 214-224. [CrossRef]

70. Halawi, H.; Camilleri, M.; Acosta, A.; Vazquez-Roque, M.; Oduyebo, I.; Burton, D.; Busciglio, I.; Zinsmeister, A.R. Relationship of gastric emptying or accommodation with satiation, satiety, and postprandial symptoms in health. Am. J. Physiol. Gastrointest. Liver Physiol. 2017, 313, G442-G447. [CrossRef]

71. Feinle, C.; Azpiroz, F. Dietary and life-style factors in funcional dyspepsia. Nat. Rev. Gastroenterol. Hepatol. 2013, 10, 150-157. [CrossRef]

72. Feinle, C.; Azpiroz, F. Dietary lipids and functional gastrointestinal disorders. Am. J. Gastroenterol. 2013, 108, 737-747. [CrossRef]

73. Hajishafiee, M.; Bitarafan, V.; Feinle-Bisset, C. Gastrointestinal Sensing of Meal-Related Signals in Humans, and Dysregulations in Eating-Related Disorders. Nutrients 2019, 11, 1298. [CrossRef]

74. Monrroy, H.; Borghi, G.; Pribic, T.; Galan, C.; Nieto, A.; Amigo, N.; Accarino, A.; Correig, X.; Azpiroz, F. Biological Response to Meal Ingestion: Gender Differences. Nutrients 2019, 11, 702. [CrossRef]

(C) 2020 by the authors. Licensee MDPI, Basel, Switzerland. This article is an open access article distributed under the terms and conditions of the Creative Commons Attribution (CC BY) license (http://creativecommons.org/licenses/by/4.0/). 